\title{
Traumatic loss and helplessness: qualitative analysis of responses in the Rorschach
}

\author{
Silvana Alba Scortegagna - Universidade de Passo Fundo, Rio Grande do Sul, Brasil \\ Anna Elisa de Villemor-Amaral - Universidade São Francisco, Itatiba, Brasil
}

\begin{abstract}
The aim in this paper is to compare the answers on the Rorschach's inanimate motion $(\underline{\mathrm{m}})$ and blood content $(\underline{\mathrm{Bl}})$ between sexual abuse victims and non-victims. Among the protocols of 76 individuals between 10 and 14 years old, 29 were selected. Qualitative analysis showed that the victims presented: a) narratives with $\underline{m}$ responses, suggesting the presence of feelings of helplessness and powerlessness; b) replies with $\underline{\mathrm{m}}$ or $\underline{\mathrm{Bl}}$ associated with contents far more violent and destructive; c) images filled with morbid characteristics. The findings support evaluation practices, illustrate the traumatic effects of sexual abuse and ascertain the validity of Rorschach's test for the ideographic approach, derived from the responses' qualitative analysis, and also from the normothetic perspective derived from the structural summary.

Key words: Psychological assessment, Rorschach, Validity, Victimization, Documentary research.
\end{abstract}

Pérdida traumática e impotencia: análisis cualitativo de las respuestas en Rorschach

\begin{abstract}
Resumen
Este trabajo se propone comparar las respuestas en Rorschach de movimiento inanimado (m) y contenido (Bl) de la sangre de las víctimas de abuso sexual y no víctimas. De protocolos de 76 personas entre 10 y 14 años de edad, se seleccionaron 29. El análisis cualitativo demostró que las víctimas eran: a) narrativas con respuestas sugestivas de la presencia de $\mathrm{m}$ sentimientos de desamparo e impotencia; b) respuestas con $\mathrm{m}$ o $\mathrm{Bl}$ asociada al contenido mucho más violento y destructivo; c) imágenes de características mórbidas. Los resultados ayudar en las prácticas evaluativas, ilustran los efectos traumáticos de abuso sexual y confirmar la validez del Rorschach a la idiográfica, enfoque proveneinte de análisis cualitativo de las respuestas, así como la perspectiva de estructural contenido extraído cerrado.

Palabras clave: Evaluación psicológica, Rorschach, Validez, Victimización, Investigación documental.
\end{abstract}

Perda traumática e desamparo: análise qualitativa das respostas no Rorschach

\begin{abstract}
Resumo
Este trabalho propõe comparar as respostas no Rorschach de movimento inanimado ( $\underline{\mathrm{m}})$ e de conteúdo sangue $(\underline{\mathrm{Bl}})$ de vítimas de abuso sexual e não vítimas. De 76 protocolos de indivíduos entre 10 e 14 anos de idade, foram selecionados 29. A análise qualitativa evidenciou que as vítimas apresentaram: a)narrativas com respostas $\underline{m}$ sugestivas da presença de sentimentos de desamparo e impotência; b) respostas com $\underline{\mathrm{m}}$ ou $\underline{\mathrm{Bl}}$ associadas a conteúdos bem mais violentos e destrutivos; c) imagens carregadas de características mórbidas. Os achados auxiliam nas práticas avaliativas, ilustram os efeitos traumáticos do abuso sexual e ratificam a validade do Rorschach para a abordagem idiográfica, proveniente de análise qualitativa das respostas, além da perspectiva nomotética extraída do sumário estrutural.

Palavras-chave: Avaliação psicológica, Rorschach, Validade, Vitimização, Pesquisa documental.
\end{abstract}

Loss is a common event present in people's lives and can represent both a growth-promoting catalyst and a burden that is difficult to manage. Everything depends on the external circumstances or internal factors referent to the ability to cope. Some variables that influence the response to trauma stem from the external stressor. This includes its magnitude and severity, as well as its unpredictability factor and duration (Carlson, Furby, Amstrong, \& Schlaes, 1997). A repetitive and highly violent event entails more severe psychological effects than relatively non-violent and unique incidents (Breslau \& cols., 1998). Other variables stem from the subject. To give an example, individuals with previous, non-elaborated trauma experiences tend to respond to a new trauma situation in a more maladaptive manner (Resnick, Yehuda, Pitman, \&Foy, 1995), just like individuals with a history of mental trauma are more predisposed to a pathological trauma response (McFarlane, 1989; Waysman, Schwarzwald, \&Solomon, 2001), due to the fragility of their adaptive resources.
A study on repetitive mistreatment episodes in childhood indicates that these experiences tend to exert a pervasive effect on personality development (Cassidy \& Mohr, 2001). Other variables involve the traumatic event in a binding situation between individuals. If a traumatic situation is provoked by another person, the trend is to arouse a more severe psychological reaction than an impersonal trauma experience, like a natural disaster (Briere, 1997). The situation gets even more acute if the bond is marked by great proximity and dependence, like in the case of incest, when the family bonds between the perpetrator and the victim enhance the probability of a Post-Traumatic Stress Disorder (PTSD) even further, entailing profound damage for the ego and relationships with other people across the lifetime (Trickett \& Putman, 1993; Van der Kolk, 2003).

Although initial studies focused on PTSD in the problems of Vietnam war veterans, other circumstances should be highlighted, such as sexual, physical and/or verbal abuse; real or perceived 
abandonment forms and the experience and/or witnessing of violent practices. Cases of childhood sexual abuse, for example, remit to an intolerable reality that can combine the experience of these three circumstances. Registers of this traumatic event go far beyond the occasional pain or physical marks the children suffer, mainly referring to the pain of perceiving that their first objects of love act towards its annihilation while, on the opposite, they should provide protection and care. The parents' infringement on the limits of the children's subjectivation, by invading them with their sexuality, reducing them to objects of their own enjoyment, signals the absence of the paternal function, entailing feelings of helplessness and severe developmental damage (Bollas, 1992).

The severity of the damage resulting from these inappropriate or insufficient conditions for children's mental constitution is directly proportional to their developmental period (Finkelhor, 1995). When these vents happen during the first formation years, for example, they can weaken the initial bases of identity construction.

One of the most devastating aspects of the traumatic experience is definitely the impact on the ego, which implies, among other things, the loss of a meaning for oneself. Consequently, the ability to think, the ability to investigate and symbolize become precarious and impair the understanding of and adjustment to the world. Damage to self-esteem, depression and anxiety symptoms are frequent, which are common in studies that aim to characterize this population in order to provide for evaluation and intervention measures, as well as to validate instruments to respond to these demands efficiently (Cerney, 1990; Clinton, \& Jenkins-Monroe, 1994; Shapiro, Leifer, Martone, Kassen, 1990).

Among the available literature, studies that use less direct and intrusive psychological investigation techniques are of interest, which permit the expression of the self through hardly structured tasks. That is so because these techniques permit revealing particularities from the internal world, in an indirect manner but free from the individual's deliberate control, and are particularly useful in situations that are susceptible to manipulation or cover-up attempts, which is the case for the Rorschach Method (Exner and Sendin, 1999).

The first studies using the Rorschach in trauma victims involved individuals in war periods, while facing a severe tempest at sea (Shalit, 1965). That study was the first to demonstrate increased inanimate motion (m) (Kaser-Boyd \& Evans, 2008), which was consistently confirmed later on in trauma research (Armstrong \& Kaser-Boyd, 2003; Holaday \&
Whittenberg,1994; Holaday, 2000; Levin \& Reis, 1997; Sloan, Arsenault \& Hilsenroth, 2002; Van der Kolk \& Ducey, 1989).

The proliferation of assessment studies in different traumatic situations present discoveries referent to the large number of $\underline{m}$ responses in Rorschach protocols. Van der Kolk and Ducey (1989) and Levin and Reis (1997) indicated $\underline{m}$ as the best discriminator between veterans with and without PTSD. Sloan et al. (2002) reported $\underline{m}$ findings in marines who served in the Gulf War, and Holaday and Whittenberg (1994) in a group of children and adolescents with severe burns. The authors concluded that the production of $\underline{m}$ responses is a sign that the individuals are experiencing a significant amount of tension, discomfort and situational stress. In accordance, other aspects attributed to $\underline{m}$ responses related to suffering, feelings of invasion by external forces and disturbing ideas and experiences of helplessness (Campo, 1980; Exner \& Sendin, 1999; Weiner, 2000; Vargas da Silva, 1987).

Some studies have attempted to determine the relation between different types of mistreatment and the Rorschach indicators. As regards sexual abuse in children, Leifer, Shapiro, Martone and Kassem (1991) measured the psychological functioning of 79 girls between five and 16 years of age, with and without a history of sexual abuse. The authors discovered that the victims differ in their high scores of distorted perception $(\underline{\mathrm{X}-\%})$; diffuse shading response ( $\underline{\mathrm{SumY}})$; special codes ( $\underline{\text { Sum6 }}$ and WSum6); uncommon and hostile contents; and responses with contents of objects penetrating others. A positive Depression Index $(\underline{D E P I})$ and drop in the number of $\underline{\mathrm{R}}$ were also verified. In summary, the sexually abused girls demonstrated more disturbed thinking, a higher stress level related to their adaptive abilities; described human relationships in a more negative form and demonstrated greater concern with sexuality than the comparative group.

It is interesting to observe that, according to some authors, children with PTSD can present, besides the presence of the schizophrenia index (SCZI), lower $\underline{X+\%}$ responses (Holaday, 2000). The research by Friedrich, Einbender and McCarty (1999) also sustained that sexual abuse victims' contact with reality was more negatively affected, as illustrated by the higher $\underline{X-} \%$ and WSum6 indices, and confirmed other findings (Leifer et al., 1991). In addition, Perfect, Tharinger, Keith and Lyle-Lahroud (2011) also reported the combined presence of personalized

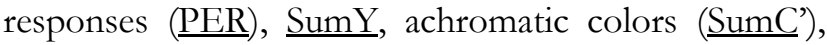
texture $(\underline{\mathrm{T}})$, and $\underline{\mathrm{PTI}}$ associated with the severity of the sexual abuse. These discoveries supported the idea that 
victims of more severe sexual abuse can turn inwards, be more defensive, internalize affection, feel powerless or be more prone to uncommon thought processes (Exner, 1993).

Other Rorschach indicators evidence that the harmful effects of mistreatment affect self-esteem. From a theoretical viewpoint, mistreated children have less possibilities of successful accomplishment to transpose the tasks of their development phase and, as a result, do not believe in their abilities to cope with challenging situations (Kim \& Cicchetti, 2006). The recent study by Perfect et al. (2011) investigated whether the Rorschach and the Minnesota Multiphasic Personality Inventory MMPI-A (Butcher \& cols., 1992) would be capable of determining the characteristics of victims of several types of mistreatment (sexual abuse, physical abuse, neglect, emotional mistreatment) and their severity. Participants included 157 adolescents, 91 girls and 66 boys, between 14 and 17 years of age, from different cultures and lowincome families.

Among the results, the Rorschach revealed lower scores on the egocentrism index (EgoIndex), increased number of morbid responses (MOR) and presence of PER responses in young abuse victims, which suggests that victims of more severe physical abuse are more susceptible to a damaged self-image. The variables $\underline{\mathrm{Afr}}$, $\underline{\text { SumY }}$ and $\underline{\text { SumC' }}$ demonstrate a significant association with different forms of mistreatment, confirming the existence of anxiety-related symptoms and attempts to avoid emotion (Clinton \& Jenkins-Monroe, 1994; Shapiro \& cols., 1990). As regards increased SumY and $\underline{\text { SumC' }}$ responses, these sustain the idea that victims of more severe sexual abuse are more prone to feeling anxious and tightening their emotions (Arnon, Maoz, Gazit, \& Klein 2011; Clinton \& Jenkins-Monroe, 1994; Leifer \& cols., 1991; Shapiro \& cols., 1990; Zimmerman \& Dillard, 1994). Evidence of a lower Afr signals the understanding that severe mistreatment victims tend to avoid emotional experiences.

In an analysis of psychological trauma in sexual abuse victims, in 90 psychodiagnosis protocols, interpreted according to the Argentinean Rorschach school, Gravenhorst (2002) found indicators that support the findings mentioned. The following stand out: small number of responses (as a result of traumatic damage experience); drop in $\underline{\mathrm{F}+\%}$ (or $\underline{\mathrm{FQ}+\%}$ in the Comprehensive System CS), and extended $\mathrm{F}+\%$ (or

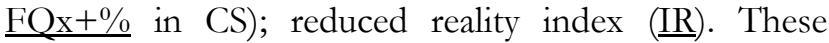
results suggest a severe pathology, associated with the operational disruption of the ego and failure to adapt to reality. Other significant elements were skeleton and blood contents; direct sexual responses (failed repression) and persecuting, aggressive and violent male figures. Some of the special phenomena were: act of tolerance in the present or past as a sign of having passively borne a violent action; and presence of $\mathrm{MOR}$ responses in the identification of damaged, destroyed, broken, dead objects.

The contents the victims identify in the ambiguous Rorschach stimuli, representing a form of reflecting internal feelings, have been reported in other studies. Some data suggest that adults who were sexually abused in childhood give responses that reflect feelings of body inappropriateness, sexual focus, and a sense of having been violated and hurt, as verified in the anatomy $(\underline{\mathrm{An}})$, sex $(\underline{\mathrm{Sx}})$ and blood $(\mathrm{Bl})$ responses (Armstrong \& Loewnstein, 1990; Friedrich \& cols., 1999; Kendall-Tackett, Williams \& Finkelhor, 1993). Leifer \& cols. (1991) found that girls who were victims of sexual abuse report sexuality concerns in responses with explicit $\underline{S_{x}}$ contents and refer to the body as broken and hurt. These concerns can reflect traumatic sexualization.

High response scores with unusual and uncommon contents, such as $\underline{\mathrm{Sx}}$ and $\underline{\mathrm{Bl}}$, were equally defined as strong sexual abuse markers (Friedrich, Jaworski, Huxahl, \& Bengston, 1997; Friedrich \& cols., 1999; Kendall-Tackett, Williams \& Finkelhor, 1993), which suggests the presence of anguish and severe damage in child victims.

In accordance with some of the data presented, a final study by Scortegagna and Villemor-Amaral (2009), in Brazil, presented some differences for the Rorschach variables in CS. The authors evaluated 76 children between 10 and 14 years of age, $64(84.2 \%)$ girls and 12 $(15.8 \%)$ boys, $36(47.4 \%)$ of whom were victims and 40 $(52.6 \%)$ non-victims of sexual abuse. Significant contributions between both groups were found in the $\underline{m}$ determinant and $\underline{\mathrm{Bl}}$ content. An, MOR, Sx and FQresponses were more frequent in the victim group. As verified, the presence of distorted self-perception and reduced self-esteem in the victims can derive from the victimization process.

If, on the one hand, there are many variables that mark the agreement among these studies, on the other, some disagreement exists. To give an example, some researchers found no changes in self-esteem with lower EgoIndex levels among adolescent sexual abuse victims when compared to the normative group (Clinton \& Jenkins-Monroe, 1994; Holaday, Armsworth, Swank, \& Vincent, 1992) or with non-victims of sexual abuse (Leifer \& cols., 1991; Owens, 1984). This was justified, considering that a damaged sense of the self has to originate in individuals with a history of severe and long-term mistreatment (Herman, 1992).

Other disagreements related to the variables $\underline{\mathrm{MOR}}, \underline{\mathrm{Afr}}, \underline{\text { SumC }}$ and $\underline{\text { SumY }}$. Some studies report on 
the enhanced presence of $\underline{\mathrm{MOR}}$ responses in the protocols of young people with a sexual abuse history than in children with chronic conditions (Shapiro, Leifer, Martone \& Kassem, 1990). Others report the opposite (Arenella \& Ornduff, 2000; Friedrich \& cols., 1999; Friedrich, Jaworski, Huxsahl, \& Bengtson, 1997) or, differently, relate these indicators with the severity and duration of the sexual abuse (Friedrich \& cols., 1999). Some studies could not find differences in Afr (Leifer \& cols., 1991; Owens, 1984), $\underline{\text { SumC or SumY }}$ (Owens, 1984) among abuse victims either. But the authors consider that these incongruences can be attributes to difficulties to better characterize the comparison groups.

As observed, further research is needed to determine whether these findings are repeated or not, as well as to verify whether there exist other forms of estimating the validity of the Rorschach to identify traumatic experiences. With that aim in mind, this research departs from the hypothesis that, beyond the frequency of indicators, differences would be verified in the qualitative analysis of responses containing $\underline{m}$ and $\mathrm{Bl}$ when comparing the expressions associated with these indicators between victims and non-victims of sexual abuse.

\section{Method}

\section{Source}

Twenty-nine protocols of individuals between 10 and 14 years of age were analyzed, which were divided in two groups: $18(62 \%)$ in the victims group, 15 $(83.3 \%)$ girls and three (16.7\%) boys, and $11(38 \%)$ in the non-victims group, nine $(81.8 \%)$ girls and two $(18.2 \%)$ boys. The children were in primary and secondary education, their socioeconomic level was characterized as medium-low, and they were obtained from the study by Scortegagna and Villemor-Amaral (2009). The analysis material only included protocols with coded answers, with the $\underline{m}$ determinant and $\underline{B l}$ contents.

The child victims had suffered intra-family sexual abuse and lived with the family or had been institutionalized. To include and exclude these participants, the following criteria were considered: a) sexual abuse incidents in which the perpetrator(s) involved a child or adolescent for his/her own satisfaction through acts like touching, kissing, caressing the genital areas, masturbating, with or without digital penetration or with the genital organ in the vagina and/or anus; b) the perpetrator was five or more years older than the child; c) at the time of data collection, the child was not living in the same place of residence as the perpetrator; d) abuse was proven as documented in the patient files.

Non-victim children attended primary and secondary public schools. To include and exclude these participants, the following participants were considered: a) not having a documented history of sexual abuse; b) not being under psychotherapeutic treatment; c) not presenting any specific learning and behavior-related complaints.

\section{Instrument}

Rorschach method - a personality research instrument that consists of 10 inkblot images, in which the subject is expected to answer the question "what does this look like". This tool was applied according to the CS (Exner, 1999).

\section{Procedure}

To achieve the study objectives, the 76 protocols from the earlier study were fully analyzed. After applying the inclusion criteria, 29 protocols remained, which were divided in two groups, one consisting of victims and another of non-victims. In the qualitative analysis of the Rorschach responses, the expressions were considered, mainly the use of qualifiers that emphasize damage suffered.

\section{Results and Discussions}

Tables 1 and 2 present the description of the protocol number, image number and Rorschach responses of the sexual abuse victims and non-victims, coded with $\underline{\mathrm{m}}$.

Table 1. Description of the child sexual abuse victims' responses with inanimate motion

(continues)

\begin{tabular}{ccc}
\hline P & Pr & Responses \\
\hline 24 & I & $\begin{array}{l}\text { 1- two people, they've got their hand raised towards each other, they are attacking each other and } \\
\text { there's blood dropping. }\end{array}$ \\
\hline 26 & I & $\begin{array}{l}\text { 3- a little bird with his wings open on top of a branch, with his beak closed and his hind legs holding } \\
\text { onto the tree. He was hurt and held onto the tree in order not to fall and his beak was closed. Here } \\
\text { there are some blood spots like in a movie I've seen. }\end{array}$ \\
\hline 8 & II $\begin{array}{l}\text { 3- blood because it's dropping and because it's red. These black things, on this side and this other side, } \\
\text { they're like a vagina because it's black and there's red and there's blood dropping from the vagina. }\end{array}$ \\
\hline
\end{tabular}


Scortegagna, S. A. \& Villemor-Amaral, A. E. Traumatic loss and Rorschach 5

Table 1. Description of the child sexual abuse victims' responses with inanimate motion

(continuation)

\begin{tabular}{|c|c|c|}
\hline $\mathrm{P}$ & $\operatorname{Pr}$ & Responses \\
\hline 23 & II & $\begin{array}{l}\text { 3- two dogs fighting because they've got two legs fighting and here there's blood coming out, in these } \\
\text { red things, because they hurt each other. }\end{array}$ \\
\hline 34 & II & 4- two black clouds meeting. It's like it's going to rain, when there's a tempest. \\
\hline 6 & III & $\begin{array}{l}\text { 5- blood too! There's blood dripping from the people's mouth because it's red, blood dropping like } \\
\text { that! }\end{array}$ \\
\hline 19 & III & $\begin{array}{l}\text { 3- A frog. The eye the nose, the chest, the leg, the mouth. He got hurt, they cast stones at him twice, } \\
\text { there's blood coming in, it got like a ball of blood, it got purple, there's red and black. }\end{array}$ \\
\hline 1 & IV & $\begin{array}{l}\text { 7-A black ship coming, because of its format. It's cloudy around it, there are some clearer parts. A } \\
\text { black ship. }\end{array}$ \\
\hline 1 & VI & $\begin{array}{l}\text { 11- An explosion in the war sea, an explosion that's happening because of the manner, the format, the } \\
\text { way it was drawn. }\end{array}$ \\
\hline 6 & VI & $\begin{array}{l}\text { 7- I think it's an open fish with blood running, that's all! There are some parts that seem like fish. I see } \\
\text { a lot of fish in the newspaper and look at those parts. More similar to blood because it looks the same } \\
\text { when it drops. }\end{array}$ \\
\hline 9 & VI & 8- Looking like this it seems like an explosion in the water. It looks like the water is jumping upwards. \\
\hline 11 & VIII & $\begin{array}{l}\text { 13- This one here's more colored, right? These two here look like a bear, except that he's got his mouth } \\
\text { open and these two here I can't tell what it is! They seem to be two birds, but their nest is breaking, } \\
\text { crumbling. Two bears and the two fattest are sitting and it seems that they wanted to eat the birdies } \\
\text { because the nest is breaking and the birds are falling. }\end{array}$ \\
\hline 18 & VIII & 14- A tree dropping on the floor. The color is similar to a tree and the shape too. \\
\hline 1 & IX & 19- It looks like a cloud 'cause it's raining, a dolphin and some trees. Cloud because of the color. \\
\hline 3 & IX & 20- A waterfall, the shape of the water that's falling. \\
\hline 6 & IX & $\begin{array}{l}\text { 10- This one's harder, there are a lot of glasses spilling juice, that's all! The shape of a glass and juice } \\
\text { spilling and the shape of a face and the tail of an animal. }\end{array}$ \\
\hline 8 & IX & $\begin{array}{l}\text { 14- Our lung because it's read and because of the shape, it looks like the digestive system, it seems that } \\
\text { we're swallowing food and everything's going down in the belly. These orange parts, the model of our } \\
\text { flesh in the belly, the color, here we've got the skin, then the bone, and then the flesh. }\end{array}$ \\
\hline 36 & IX & $\begin{array}{l}\text { 12- The liver of a person bleeding because it's big, because the blood is red and kind of black and the } \\
\text { flesh is black, because there's kind of one darker and one lighter color. }\end{array}$ \\
\hline 3 & $\mathrm{X}$ & 25- two algae eating fish, similar because of the way it is. \\
\hline 24 & $\mathrm{X}$ & $\begin{array}{l}\text { 16- violence mixed with joy, with flowers... bloodstains, a lot of evil there, a lot of blood... I see } \\
\text { animals, people fighting who live with the evil inside themselves, I see blood stains dropping onto } \\
\text { people, I see flowers representing joy and people and blood stains representing the evil, so I see evil } \\
\text { mixed with job, animals mixed with human beings. It's in the drawing. }\end{array}$ \\
\hline
\end{tabular}

Table 2. Description of the responses of children non-victims of sexual abuse with inanimate motion (continues)

\begin{tabular}{ccl}
\hline $\mathrm{P}$ & $\operatorname{Pr}$ & \multicolumn{1}{c}{ Responses } \\
\hline 42 & I & $\begin{array}{l}\text { 2- Some angels here at the side, it seems that they're in a circle. The shape of the dress flying, the } \\
\text { hands, that's it! }\end{array}$ \\
\hline 65 & VI & 7- A woman standing with a detail of the dress that's spreading. \\
\hline 73 & VI & 7- It looks like a woman, here dress is flying as if there were wind. \\
\hline 47 & IV & $\begin{array}{l}\text { 5- A monster, it has a tail and the head has the shape of a snake, it seems... and it looks like he's made } \\
\text { out of smoke, kind of... there's kind of smoke rising. }\end{array}$ \\
\hline 64 & VII & $\begin{array}{l}\text { 10- Two women dancing. The woman's head, the hair stuck flying upwards and the lower limbs, the } \\
\text { arms, the hand. }\end{array}$ \\
\hline 49 & IX & $\begin{array}{l}\text { 11- A palm tree and a waterfall dropping... the water is coming down and the palm tree is standing in } \\
\text { the middle. }\end{array}$ \\
\hline 44 & IX & $\begin{array}{l}\text { 11- A medieval sword in the middle and some walls that are coming inwards, moving towards the } \\
\text { sword. }\end{array}$ \\
\hline 63 & X & 14- It looks like water, a beak, when we're casting stones inside. It looks like water rising. \\
\hline
\end{tabular}

Psico-USF, Bragança Paulista, v. 18, n. 1, p. 1-12 jan./ abril 2013 
Table 2. Description of the responses of children non-victims of sexual abuse with inanimate motion (continuation)

\begin{tabular}{ccl}
\hline $\mathrm{P}$ & $\mathrm{Pr}$ & \multicolumn{1}{c}{ Responses } \\
\hline 65 & $\mathrm{X}$ & 15- A broken egg and the yolk dripping. \\
\hline 66 & $\mathrm{X}$ & 23- A dragon, the smoke coming out of his nose and the tipped ears, the long face. \\
\hline 43 & $\mathrm{X}$ & $\begin{array}{l}\text { 16- A destroyed river, with the margin completely destroyed, all dropped, broken because of the way it } \\
\text { spread. It's crossing a forest. }\end{array}$ \\
\hline 75 & $\mathrm{X}$ & $\begin{array}{l}\text { 15- A very evil guy, he's smiling. He's got glasses that are dropping and two horns holding two } \\
\text { pompons. Colored leaves are falling. }\end{array}$ \\
\hline
\end{tabular}

$\mathrm{P}=$ Protocol number $/ \mathrm{Pr}=$ Image number

As observed in Table 1, the $\underline{m}$ types lead to considerations about how victims see themselves and perceive objects. One of the core aspects of motion responses in general is to give meaning to experiences, to experiences of life, which lead to the understanding of psychic representations, that is, of how they start to constitute the internal world (Vargas da Silva, 1987). In these circumstances, the $\underline{m}$ responses seem to express aspects related to the victims' suffering, which Weiner (2000) described as an intense activity of non-deliberate disturbing ideas, thoughts of anguish and powerlessness to prevent situations that affect their own destiny. Exner and Sendín (1999) also understand these characteristics, commonly found in individuals with PTSD (Levin \& Reis, 1997; Van der Kolk \& Ducey, 1989), as experiences of helplessness.

Similarly, this understanding can be compared to what Campo (1980) describes when indicating that the $\underline{\mathrm{m}}$ responses reveal feelings of threat and invasion by external forces, without control by an extremely fragile and vulnerable ego. According to the author, the experience of this situation of internal danger arouses feelings of conflict that take the form of irritability, anguish or depression, which was also confirmed in other studies (Armstrong \& Kaser-Boyd, 2003; Holaday \& Whittenberg, 1994; Holaday, 2000; Levin \& Reis, 1997; Sloan, Arsenault \& Hilsenroth, 2002). Among the images referred, the following stand out: "some blood drops are falling", "blood is falling", "blood streaming", "nest... it's breaking, crumbling", "a lot of blood falling onto the people". It should be observed that the qualitative aspect the object movement is involved in relates to something that is falling, which according to Weiner (2000) can provoke the deduction that something bad is happening, with a complete loss of voluntary control.

In addition, it is important to observe that most $\underline{\underline{m}}$ responses in the child victim group have been associated with $\underline{\mathrm{B}}, \underline{\mathrm{An}}$ and $\underline{\mathrm{Sx}}$ contents, which points towards the existence of a fragile ego, threated by forces beyond control, within a context of attack against the body. The high response indices with unusual and uncommon contents, such as $\underline{\mathrm{S}}$ and $\underline{\mathrm{Bl}}$, were reported as a strong indicator of sexual abuse
(Kendall-Tackett, Williams \& Finkelhor, 1993) supporting the presence of anguish and signs that the children are suffering severe damage, are invaded and hurt, in accordance with earlier studies (Armstrong \& Loewnstein, 1990; Friedrich \& cols., 1999; Gravenhorst, 2002).

Another frequent association is between $\underline{m}$ and

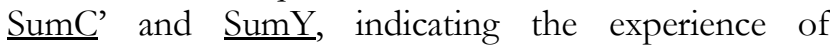
persecutory feelings related to the condition of being a victim, invading anxiety, beyond control. These are related to the emotional experiences of helplessness (Exner, 2003) and, as observed, support the idea that victims of more severe sexual abuse are more prone to feeling anxious and tightening their emotions (Clinton \& Jenkins-Monroe, 1994; Leifer \& cols., 1991; Shapiro \& cols., 1990; Zimmerman \& Dillard, 1994).

Among responses with these characteristics, the following expressions are highlighted: "two black clouds meeting", "a black ship coming", "the liver of a person bleeding because it's, kind of, one darker and one lighter color". Also, the motion responses reflect the presence of a synesthetic feeling, as something that is being experienced but which, in the case of $\underline{m}$, beyond a human condition, induces thoughts about a more direct and still present relation with the traumatic experience process.

For the sake of a better explanation, it is important to analyze the $\underline{m}$ responses in the group of non-victims (Table 2) in order to grasp the dimension that not just the frequency, but the type of expression indicates a feeling of control loss, as $\underline{m}$ does not cease to have its common implications, but not destructive and disorganizing like in the earlier answers. In this segment, the narratives gain milder contents, without devastating and violent connotations. Themes of typical female clothing are referred, highlighting gender narcissism and identification (Vargas da Silva, 1987), keeping in mind that most participants in the sample are girls. The expressions include: "dress flying", "dress spreading", "waterfall dropping", "walls moving inwards", "water rising", "yolk running", "smoke escaping", "leaves dropping".

In the comparison between the two groups, the expressions of abuse victims' $\underline{m}$ responses mainly differ 
because they are loaded with elements that emphasize $\underline{\mathrm{Bl}}$ and $\underline{\mathrm{AG}}$ contents, in which the devastating and violent aspect is dominant. The effects of destructive trends emerge in the narratives as "attacking each other", "blood in the vagina", "fighting", "explosion", "stone-throwing", "nest crumbling and birds falling", "liver bleeding", among others. Next, in Tables 3 and 4 , the protocol number, image number and the sexual abuse victims and non-victims' responses are presented, coded with $\underline{\mathrm{Bl}}$ contents, respectively.

Table 3. Description of the child sexual abuse victims' responses with blood contents

(continues)

\begin{tabular}{|c|c|c|}
\hline $\mathrm{P}$ & $\operatorname{Pr}$ & Responses \\
\hline 24 & $\mathrm{I}$ & $\begin{array}{l}\text { 1- Two people, they've got their hand raised towards each other, they are attacking each other and } \\
\text { there's blood dropping. }\end{array}$ \\
\hline 26 & I & $\begin{array}{l}\text { 3- A little bird with his wings open on top of a branch, with his beak closed and his hind legs holding } \\
\text { onto the tree. He was hurt and held onto the tree in order not to fall and his beak was closed. Here } \\
\text { there are some blood spots like in a movie I've seen. }\end{array}$ \\
\hline 1 & II & $\begin{array}{l}\text { 3- It looks like two animals that were attacked and they're bleeding, two bears are bleeding, there are } \\
\text { some red things, they shot them, they were attacked and they're dragging each other. There are a lot of } \\
\text { people who hunt bears. }\end{array}$ \\
\hline 5 & II & 4- A dead animal because there's blood... the entire body, dead, because there's this red thing. \\
\hline 8 & II & $\begin{array}{l}\text { 3- Blood because it's dropping and because it's red. These black things, on this side and this other side, } \\
\text { they're like a vagina because it's black and there's red and there's blood dropping from the vagina. }\end{array}$ \\
\hline 11 & II & $\begin{array}{l}\text { 4- It looks like a woman's vagina, it looks as if she's having her period. Vagina because I looked in the } \\
\text { books and period because the blood is red. }\end{array}$ \\
\hline 18 & II & 3- A stained sheet. Blood mixed with dirt... it looks like it because of the red stains... \\
\hline 23 & II & $\begin{array}{l}\text { 3- Two dogs fighting because they've got two legs fighting and here there's blood coming out, in these } \\
\text { red things, because they hurt each other... }\end{array}$ \\
\hline 24 & II & $\begin{array}{l}\text { 2- It seems to be part of two people who were violated, there's part of the body missing. There's a piece } \\
\text { of the head missing, blood stain, it's all dirty with read... there's a piece of the head missing, it's dirty } \\
\text { with blood }\end{array}$ \\
\hline 25 & II & $\begin{array}{l}\text { 4- Blood from the throat... because of the ugly animal's throat, I don't like watching blood, ugly animal, } \\
\text { ghost... I can't see blood, when there's blood coming from my nose I get frightened. }\end{array}$ \\
\hline 29 & II & 5- Blood, there are some red things there, that's all! \\
\hline 31 & II & $\begin{array}{l}\text { 2- Two mice and bloodstains. Two mice because they've got big ears and they're slapping their hands... } \\
\text { there's blood up here, there are bloodstains because when the mice eat animals there's blood, it's similar } \\
\text { because it's red }\end{array}$ \\
\hline 34 & II & $\begin{array}{l}\text { 3- It looks like two dead animals. It looks like a dog run over because there are red stains, blood, part of } \\
\text { the head and the other... here there's one dog and here another. }\end{array}$ \\
\hline 35 & II & $\begin{array}{l}\text { 3- Two mice dirty with blood, the legs, the ears, the nose, blood, because there are the stains and the } \\
\text { color is red }\end{array}$ \\
\hline 36 & II & $\begin{array}{l}\text { 2- A crushed cockroach because it's a bit black and a bit brown... it looks a bit fat and because of the } \\
\text { blood. There's a crushed scorpion... it's fat and when it breaks at the side like this one here, he went to } \\
\text { catch the cockroach and the car came and hit both... }\end{array}$ \\
\hline 8 & III & 5- Blood too! There's blood dripping from the people's mouth because it's red, blood dropping like that! \\
\hline 18 & III & $\begin{array}{l}\text { 5- Two little dead animals, blood spread too. The animals were dead and then I saw blood too, in this } \\
\text { red. }\end{array}$ \\
\hline 19 & III & $\begin{array}{l}\text { 3- A frog. The eye the nose, the chest, the leg, the mouth. He got hurt, they cast stones at him twice, } \\
\text { there's blood coming in, it got like a ball of blood, it got purple, there's red and black. }\end{array}$ \\
\hline 25 & III & $\begin{array}{l}\text { 5- It looks like a woman's breast, there are two women, they're fighting because of the breasts, they } \\
\text { want the breasts for them. This red looks like blood and it's similar to a breast. }\end{array}$ \\
\hline 25 & III & 7- A pig with the paws, there's the nose and some red blood that sprung from the pig's eye, that's it. \\
\hline 36 & III & $\begin{array}{l}\text { 3- A frog crushed by the care, his head and the paws and a piece of the body, you can't see it all because } \\
\text { the car passed and hit him, you can see his blood. There's the frog's eye here, it cut the frog's eye and } \\
\text { there was water coming out, because it got like, filled with little curves. }\end{array}$ \\
\hline
\end{tabular}


Table 3. Description of the child sexual abuse victims' responses with blood contents

(continuation)

\begin{tabular}{|c|c|c|}
\hline $\mathrm{P}$ & $\operatorname{Pr}$ & Responses \\
\hline 6 & VI & $\begin{array}{l}\text { - I think it's an open fish with blood running, that's all! There are some parts that seem like fish. I see a } \\
\text { lot of fish in the newspaper and look at those parts. More similar to blood because it looks the same } \\
\text { when it drops. }\end{array}$ \\
\hline 8 & VIII & $\begin{array}{l}\text { 13- The body here and the mouse inside us walking and the dead person and the mouse inside, the } \\
\text { shape, when the body is kind of dirty with blood. Blood because it's red. }\end{array}$ \\
\hline 18 & IX & 15- I don't know this one... blood, there's a kind of bloodstain. The color is kind of similar. \\
\hline 24 & $\mathrm{X}$ & $\begin{array}{l}\text { 16- Violence mixed with joy, with flowers... bloodstains, a lot of evil there, a lot of blood... I see } \\
\text { animals, people fighting who live with the evil inside themselves, I see blood stains dropping onto } \\
\text { people, I see flowers representing joy and people and blood stains representing the evil, so I see evil } \\
\text { mixed with job, animals mixed with human beings. It's in the drawing. }\end{array}$ \\
\hline 25 & IX & 18- A rainbow. It's the same, it's dirty with blood. \\
\hline 36 & IX & $\begin{array}{l}\text { 12- The liver of a person bleeding because it's big, because the blood is red and kind of black and the } \\
\text { flesh is black, because there's kind of one darker and one lighter color. } \\
\text { 13- A spine here because a person's spine is straight, like this here, otherwise the person gets curved, } \\
\text { there's the vein passing here on top in this little red thing! Here the blood from the vein, bright red } \\
\text { because the blood that's passing through the vein! }\end{array}$ \\
\hline
\end{tabular}

$\mathrm{P}=$ Protocol number $/ \mathrm{Pr}=$ Image number

Table 4. Description of the responses of children non-victims of sexual abuse with blood contents

\begin{tabular}{ccl}
\hline $\mathrm{P}$ & $\mathrm{Pr}$ & Responses \\
\hline 63 & II & 4- Bloodstains, the shape. Perhaps the bottom one is a butterfly. \\
\hline 65 & II & 2- Two bloodstains because each time we get cut it gets like that, it looks like it dripped. \\
\hline 55 & III & 4- Blood, it looks like a bloodstain because of the red color and the shape. \\
\hline
\end{tabular}

The responses to the colored stimulus in the Rorschach are considered related to the type of resonance and management of the emotional impact. Images II and III, for example, differently from images VIII, IX, X, with multiple colors in overlapping and clearer nuances, intensely show bright red in contrast with black, and tend to arouse more primitive emotions like aggressiveness, or emotions linked with sexuality (Weiner, 2000).

In view of this stimulus, both child victims and non-victims gave more $\underline{\mathrm{Bl}}$ responses, precisely related to images II and III, but in a quantitative and qualitatively very diverse form. In the victim group, $\underline{\mathrm{Bl}}$ responses were abundant, loaded with disturbing, aggressive and violent elements, such as "dog run over", "dirty with blood", "frog crushed", "mice eating insects and there's blood", "dead animals". The human and animal motion projected also appears imbued with violent interactions, including "two people, one wanting to attack the other", "two dogs fighting", "women fighting". Other narratives reveal the conditions of vulnerability and lack of protection in the persistent identification of small and hardly powerful creatures, like a little bird, little mice, cockroach, little animals. In the non-victim group, only three responses contained Bl, without aggressive interactions with humans or animals and, also, hardly destructive, that is, imbued with a situation that can happen in daily life at home, like cutting oneself.

Finally, it is important to highlight another type of content that appears in the MOR responses which, despite the lack of a significantly higher statistical frequency in the victim group, appear more numerously among these children, even when not accompanied by $\underline{\mathrm{m}}$ and $\underline{\mathrm{Bl}}$. Table 5 exemplifies these responses. 
Table 5. Description of the child sexual abuse victims' responses with morbid contents

\begin{tabular}{|c|c|c|}
\hline $\mathrm{P}$ & $\operatorname{Pr}$ & Responses \\
\hline 36 & II & $\begin{array}{l}\text { 2- A crushed cockroach because it's a bit black and a bit brown... it looks a bit fat and because of the } \\
\text { blood. There's a crushed scorpion... it's fat and when it breaks at the side like this one here, he went } \\
\text { to catch the cockroach and the car came and hit both... }\end{array}$ \\
\hline 36 & III & $\begin{array}{l}\text { 3- A frog crushed by the care, his head and the paws and a piece of the body, you can't see it all } \\
\text { because the car passed and hit him, you can see his blood. There's the frog's eye here, it cut the frog's } \\
\text { eye and there was water coming out, because it got like, filled with little curves. }\end{array}$ \\
\hline 36 & IV & $\begin{array}{l}\text { 4- A crushed mouse... the mouse's head, the paws and the piece of the body. It looks like his tail was } \\
\text { divided and went to the sides, it's wide, it's big, it went to the sides, it got fat, that's why it looks like a } \\
\text { mouse, I know mice! It got crushed! }\end{array}$ \\
\hline 24 & IV & $\begin{array}{l}\text { 7- It looks like the rest of the body of a person who was forced to sexual violence, until death, there } \\
\text { are just remnants, the rest of the face is missing, the part of the head, the arms are missing, forced to } \\
\text { death. }\end{array}$ \\
\hline 25 & IV & 7- A human rib bone, here, the bone has fallen, it's broken. \\
\hline 36 & $\mathrm{~V}$ & $\begin{array}{l}\text { 5- A crushed bat... the hind legs and the wings as I said in the other... the wings are filled with curves, } \\
\text { the head crushed, two little sticks are left and the hind legs where he gets top-down... the hind legs } \\
\text { because I see it on Globo reporter! }\end{array}$ \\
\hline 8 & VI & 8- A trodden snail... because it seems all shattered, this shape of the head, it's similar to a snail. \\
\hline 11 & VI & 10- It looks like a penis with a condom all blown up, it's totally blown up. \\
\hline 36 & VII & $\begin{array}{l}\text { 8- A crushed butterfly... here's the middle and here the wings, because there's the line in the middle } \\
\text { and there's the head... the body... the wings... because butterfly is like, the wings are full of curves. }\end{array}$ \\
\hline 36 & VII & $\begin{array}{l}\text { 9- A crushed frog... it's similar it has the shape of a frog, there are two crushed frog legs... because } \\
\text { the feet so straight, it should be more round and it isn't, it's more straight because the car passed on } \\
\text { top! }\end{array}$ \\
\hline 19 & VII & 9- A butterfly, they pulled off the head, the legs, her body, they just left the wing. \\
\hline 19 & VII & $\begin{array}{l}\text { 10- It looks like a dog, the legs, two dogs that divided the neck in the middle, and they put it together } \\
\text { and the legs on top of them. }\end{array}$ \\
\hline 8 & VIII & $\begin{array}{l}\text { 13- The body here and the mouse inside us walking and the dead person and the mouse inside, the } \\
\text { shape, when the body is kind of dirty with blood. Blood because it's red. }\end{array}$ \\
\hline 19 & $\mathrm{X}$ & $\begin{array}{l}\text { 15- A headless mule, it's releasing fire. There are two animals that eat carrion, they're fighting... they } \\
\text { pulled off a leg... A big pig that was killed and two piglets the headless mule is eating from behind... }\end{array}$ \\
\hline 23 & $\mathrm{X}$ & 17- The shape of the bone of the body, the body is cast and the animals are eating... \\
\hline 25 & $\mathrm{X}$ & 21- A crushed breast, that's the idea. \\
\hline
\end{tabular}

Initially, it is noteworthy that six out of ten responses indicated above come from the same child (P 36), who in turn gave few $\underline{\mathrm{m}}(1)$ and $\underline{\mathrm{Bl}}$ responses (three, two of which contained MOR), demonstrating that, in this case, the perception of the ruined and lifeless body is a much more acute indicator of the damage suffered. Therefore, the perception of a damaged or unworthy body, an even fragmented or injured sense of the self in sexual abuse victims, in comparison with non-victims, were equally identified through the MOR responses (Table 5), in line with the literature (Gravenhorst, 2002; Perfect \& cols., 2011). Beyond the implications of the quantitative increase in these responses in the victim group, the qualitative approach seems to reveal the children's perceptions of a destroyed or malfunctioning body, with unwanted characteristics, reflecting the identification with a damaged, dilacerated body, victim of an aggression.

Psico-USF, Bragança Paulista, v. 18, n. 1, p. 1-12 jan./ abril 2013
The responses issues indicate an identification of the abuse victims as internally experiencing a suffered and fragmented body, in which the abusive acts were experienced as highly intruding, capable of compromising the development of the sense of self. The frequent expressions of the contents crushed can express signs of lack of prohibition, of an adverse environment, and of violence against the body passively undergone (Gravenhorst, 2002). The recursive images evoked as "crushed cockroach", "crushed frog", "a crushed mouse", "a crushed bat", "a trodden snail", "crushed butterfly", witness the bodily and psychic damage, an annihilated, dilacerated and dead body.

These expressions also indicate the choice of small and hardly powerful or repugnant animals, like the mouse, cockroach, frog, snail, which appear represented as victims of an aggression, support a 
clearly consumed identification with fragile objects that cause disgust, revealing a highly depreciated image. According to Weiner (2000), like in the case of human figures, an emphasis on small animals indicates the possibility that subjects consider themselves as worthless, insignificant, and that they can be easily trodden. The recurrent morbid thematic contents are frequently associated with recent loss experiences and thematic situations, as easily perceived in the qualitative analysis.

\section{Final Considerations}

In the Rorschach, the subjects' responses to the stimuli can be loaded with dislocated representations and affections. When this happens, the narratives in view of the images reveal a close associative correspondence with the experiences lived and with the symbolic world.

In these circumstances, while the repetition of thematic contents can be objectively determined by counting its frequency, considering the ratios, proportions and derivations, assessing whether an image is dramatic requires not only a quantitative, but also a qualitative approach of the data (Weiner, 2000), considering word for word what is said in the composition of the image visualized.

With that aim, this study showed interesting results. As verified: a) the expressions of $\underline{m}$ responses in abuse victims, differently from non-abuse victims, suggested the presence of feelings of helplessness and powerlessness, associated with external circumstances beyond control, which therefore serve as an alarm, a sign of conflict and tension, resulting from the victimization; b) the content of the abuse victims' expressions containing $\underline{\mathrm{m}}$ or $\underline{\mathrm{Bl}}$ was far more violent and destructive than the few cases expressed by nonvictims; c) the child abuse victims who did not reveal the $\underline{\mathrm{m}}$ determinant or $\underline{\mathrm{Bl}}$ contents reported destroyed images loaded with morbid characteristics.

These elements illustrate some of the devastating effects of sexual abuse on the victims and are in line with earlier studies that support the utility of the Rorschach, regarding both the identification of these situations and the support they demand. In addition, they refer to the awareness that the effects of sexual abuse are not monolithic and demand further attention to these children's individual needs. The belief that the Rorschach is a more appropriate instrument to understand trauma victims' psychological functioning, inform about resulting chronic effects and help to direct treatment was again reported in recent studies (Katsounari \& Jacobowitz, 2011; Perfect \& cols., 2011).
Finally, although the qualitative approach is more aligned with an idiographic perspective and the study sample is relatively limited, these results can somehow be generalizable or should at least serve as signals for further case by case investigation. Research should definitely continue, mainly involving male victims, who were very limited in this sample. Such studies can support the present findings or not and enrich the research and knowledge process in this area.

\section{References}

Arenella, J., \&Ornduff, S. R. (2000). Manifestations of bodily concern in sexually abused girls. Bulletin of the Menninger Clinic, 64, 530-542.

Arnon Z., Maoz, G.,Gazit,T., \& Klein, E. (2011). Rorschach indicators of PTSD - A retrospective study. Rorschachiana, 32, 5-26.

Armstrong, J. G., \& Loewenstein, R. J. (1990). Characteristics of patients with multiple personality and dissociative disorders on psychological testing. Journal of Nervous and Mental Disorders, 178, 448-454.

Armstrong, J., \& Kaser-Boyd, N. (2003). Projective assessment of psychological trauma. In $\mathrm{M}$. Hilsenroth\& D. Segal (Eds.), Comprehensive handbook of psychological assessment, Vol. 2. Objective and prospective assessment of personality and psychology (pp. 500-512). New York: Wiley.

Blos, P. (1979). The adolescent passage. New York: International Universities Press.

Bollas, C. (1992). A sombra do objeto: psicanálise do conhecido não-pensado. Rio de Janeiro: Imago.

Breslau, N., Kessler, R.C., Chilcoat, H.D., Schultz, I.R., Davis, G.C. \& Andreski, P.C. (1998).Trauma and posttraumatic stress disorder in the community. American Journal of Psychiatry, 55, 626-632.

Briere, J. (1997). Psychological assessment of adult posttraumatic states. Washington, DC: American Psychological Association.

Butcher, J. N., Williams, C. L., Graham, J. R., Archer, R. P., Tellegen, A., Ben-Porath, Y. S., \& Kemmer, B. (1992). MMPI-A: Minnesota Multiphasic Personality Inventory Adolescent: Manual for administration, scoring, and interpretation. Minneapolis: University of Minnesota Press.

Carlson, E.B., Furby, L., Amstrong, J., \&Schlaes, J. (1997). A conceptual framework for the long-term psychological effects of traumatic childhood abuse. Child Maltreatment, 2, 272-295.

Cassidy, J., \& Mohr, J.J. (2001).Unsolvable fear, trauma, and psychopathology. Clinical Psychology: Science and Practice, 8, 275-298. 
Campo, V. (1980). Acerca del significado de las respuestas de movimiento inanimado (m). Revista de la Sociedad Espanola del Rorschach y Metodos Proyectivos. Retrieved on February 24th 2012 from http://pt.scribd.com/doc/111864264/Respuestas -Movimiento-Inanimado-en-Ro

Cerney, M.S. (1990). The Rorschach and Traumatic Loss: Can the Presence of Traumatic Loss Be Detect From de Rorschach? Journal of Personality Assessment, 55, 781-789.

Clinton, G. T., \& Jenkins-Monroe, V. (1994). Rorschach responses of sexually

abused children: An exploratory study. Journal of Child Sexual Abuse, 3, 67-84.

Exner, J. E., Jr. (1993). The Rorschach: A comprehensive system: Vol. 1. Basic foundations (3rd ed.). New York: Wiley.

Exner, J., Jr. (2003). The Rorschach: A Comprehensive System (4. ed.). New York: John Wiley \& Sons.

Exner, J. E. Jr. \& Sendin, C. (1999). Manual de Interpretaça do Rorschach para o Sistema Compreensivo. São Paulo: Casa do Psicólogo.

Finkelhor, D. (1995). The victimization of children: a developmental perspective. American Journal of Orthopsychiatry, 65, 177-193.

Friedrich, M. N., Jaworski, T. M., Huxsahl, J. E. \& Bengtson, B.S. (1997). Dissociative and sexual behaviors in children and adolescents with sexual abuse and psychiatric histories. Journal of Interpersonal Violence, 12 (2), 155-158.

Friedrich, W. N., Einbender, A. J., \& McCarty, P. (1999). Sexually abused girls and their Rorschach responses. Psychological Reports, 85, 355-362.

Gravenhorst, M. C. (2002). Rorschach psychodiagnosis of psychic trauma in sexually abused children. In A. Andronikof (Ed). Rorschachiana XXV: Yearbook of the International Rorschach Society (pp.77-85). Ashland, OH, US: Hogrefe \& Huber Publishers, VII.

Herman, J. L. (1992). Trauma and recovery. New York, NY: Basic Books.

Holaday, M. (2000). Rorschach protocols from children and adolescents diagnosed with posttraumatic stress disorder. Journal of Personality Assessment, 75 (1), 143-157.

Holaday, M., Armsworth, M., Swank, P., \& Vincent, K. (1992). Rorschach responding in traumatized children and adolescents. Journal of Traumatic Stress, 5, 119-129.

Holaday, M., \& Whittenberg, T. (1994). Rorschach responding in children and adolescents who have been severely burned. Journal of Personality Assessment, 62, 269-279.
Katsounari, J., \& Jacobowitz, J.A. (2011). Comparative Analysis of MMPI and Rorschach Findings Assessing Combat-Related PTSD in Vietnam Veterans. Psychology, 2 (4), 335-341.

Kaser-Boyd, N., \& Evans, F.B. (2008). Rorschach assessment of psychological trauma. In C.B. Gacono \& B. Evans (Eds). The Handbook of Forensic Rorschach Assessment_(pp. 255-277).New York: Routledge.

Kendall-Tackett, K. A., Williams, L. M. \& Finkelhor, D. (1993). Impact of sexual abuse on children: A review and synthesis of recent empirical studies. Psychological Bulletin, 113,164-180.

Kim, J., \& Cicchetti, D. (2006). Longitudinal trajectories of self-system processes and depressive symptoms among maltreated and nonmaltreated children. Child Development 277, 624-639.

Leifer, M., Shapiro, J. P., Martone, M. W., \& Kassem, L. (1991). Rorschach assessment of psychological functioning in sexually abused girls. Journal of Personality Assessment, 56, 14-28

Levin, P., \& Reis, B. (1997). Use of the Rorschach in assessing trauma. In J.P. Wilson \& T.M. Keane (Eds.), Assessing psychological trauma and PTSD (pp. 529-543). New York: Guilford.

McFarlane, A.C. (1989). The etiology of posttraumatic morbidity: Predisposing, precipitating and perpetuating factors. British Journal of Psychiatry, 154, 221-228.

Owens, T. H. (1984). Personality traits of female psychotherapy patients with a history of incest: A research note. Journal of Personality Assessment, 47, 606-608.

Perfect, M. M, Tharinger, D.J., Keith, T.Z., \& LyleLahroud, T.(2011). Relations Between Minnesota Multiphasic Personality Inventory-A Scales and Rorschach Variables With the Scope and Severity of Maltreatment Among Adolescents. Journal of Personality Assessment,_93 (6), 582-591.

Resnick, H.S., Yehuda, R., Pitman, R.K., \& Foy, D.W. (1995). Effect of previous trauma on acute plasma cortical level following rape._American Journal of Psychiatry, 152, 1675-1677.

Scortegagna, S.A., \& Villemor-Amaral, A.E. (2009). Autopercepção no Rorschach de vítimas de abuso sexual infantil. Psico,_40 (3), 328-336.

Shalit, B. (1965). Effects of environmental stimulation on the M,FM and $\mathrm{m}$ responses in the Rorschach. Journal of Projective Techniques and Personality Assessment, 29, 228-231.

Shapiro, J. P., Leifer, M., Martone, M. W., \& Kassem, L. (1990). Multimethod assessment of depression in sexually abused girls. Journal of Personality Assessment, 55, 234-248. 
Sloan, P., Arsenault, L., \& Hilsenroth, M. (2002). Use of the Rorschach in the assessment of war-related stress in military personnel. Rorschacbiana. Yearbook of International Rorschach Society, 25, 86-122.

Trickett, P.K., \& Putman, F.W. (1993). Impact of child sexual abuse on females._Psychological Science, 4, 8187.

Van der Kolk, B. A. (2003). The neurobiology of childhood trauma and abuse. Child and Adolescent Psychiatric Clinica, 12, 293-317.

Van der Kolk, B. A. (1985). Adolescent vulnerability to posttraumatic stress disorder._Psychiatry, 48, 365370.

Van der Kolk, B. A., Blitz, R., Burr, W., Sherry, S., \& Hartmann, E. (1984). Nightmares and trauma: A comparison of nightmares after combat with lifelong night in veterans. American Journal of Psychiatry, 141, 187-190.

Van der Kolk, B. A., \&Ducey, C. P. (1989). The psychological processing of traumatic experience:
Rorschach patterns in PTSD. Journal of Traumatic Stress, 2,259-275.

Vargas da Silva, M.D. (1987). Rorschach uma abordagem psicanalitica. São Paulo: EPU.

Waysman, M., Schwarzwald, J., \& Solomon, Z. (2001). Hardiness: An examination of its relationship with positive and negative long term changes following trauma. Journal of Traumatic Stress, 14, 531-548.

Weiner, I. B. (2000). Princípios da Interpretação do Rorschach. São Paulo: Casa do Psicólogo.

Zimmerman, D. P., \& Dillard, J. (1994). The Rorschach assessment of sexually abused children in residential treatment: A research note. Residential Treatment for Children \& Youth,12, 59-72.

Sobre as autoras:

Recebido em: 19/11/2012

Reformulado em: 19/03/2013

Aprovado em: 03/04/2013

Silvana Alba Scortegagna: Ph.D. in Psychology, Universidade São Francisco. Professor, Stricto Sensu Graduate Program in Human Aging, Universidade de Passo Fundo.

Anna Elisa Villemor-Amaral: Ph.D. in Sciences, Unifesp/EPM. Post-Doctoral degree, Université de Savoie, France. Associate Professor, Stricto Sensu Graduate Program in Psychology, Universidade São Francisco.

Contato com as autoras:

Universidade de Passo Fundo

Curso de Psicologia - IFCH

Campus I, BR 285 - Bairro São José - Caixa Postal 611 - CEP 99001-970 - Passo Fundo/RS, Brasil.

E-mail: silvanalba@upf.br; silvanascortegagna@gmail.com 